\title{
EFFECTS OF IRRADIANCE ON NON-STRUCTURAL CARBOHYDRATES, GROWTH, AND HYPOGLYCEMIC ACTIVITY OF Rhynchelytrum repens (WILLD.) C.E. HUBB. (POACEAE)
}

\author{
SOUZA, A., De PAULA, A. C. C. F. F. and FIGUEIREDO-RIBEIRO, R. C. L. \\ Instituto de Botânica, Seção de Fisiologia e Bioquímica de Plantas, C.P. 4005, \\ CEP 01061-970, São Paulo, SP, Brazil \\ Correspondence to: Rita de Cássia L. Figueiredo-Ribeiro, Instituto de Botânica, Seção de Fisiologia e Bioquímica \\ de Plantas, C.P. 4005, CEP 01061-970, São Paulo, SP, Brazil, e-mail: ritarib@usp.br \\ Received February 14, 2003 - Accepted April 25, 2003 - Distributed August 31, 2004
}

(With 7 figures)

\begin{abstract}
Irradiance is a crucial factor in plant development. Different radiant energy levels cause different responses related to plant growth and the production and distribution of dry matter. Considering the relationship between light availability and metabolism of carbohydrates and derived compounds, the aim of this work was to assess the effects of irradiance on non-structural carbohydrate contents and composition, as well as on the hypoglycemiant activity of Rhynchelytrum repens, a pantropical grass species popularly used for diabetes treatment. Plants of $R$. repens growing under natural irradiance (NI) showed increased content of total soluble carbohydrate (TSC), higher fluctuations in starch content (SC) and higher number of tillers. The flowering process of these plants was preceded by an increase in sucrose. However, their water content was low when compared to that of plants cultivated under low irradiance (LI). The ratio root/aerial organs and SC showed no significant differences in plants grown under LI, although TSC increased and a lower number of tillers were observed during the experimental period. In both conditions, sucrose was the ubiquitous sugar and seemed to be involved in the flowering process. A reduction in the blood sugar level was observed through the intra-peritoneal (IP) administration of the precipitate of aqueous extracts obtained from plants growing in both conditions of light; the supernatant fraction showed no hypoglycemic effect.
\end{abstract}

Key words: tropical grasses, soluble sugars, hypoglycemic activity, low irradiance.

\section{RESUMO}

Efeitos da irradiância sobre o crescimento, carboidratos não-estrututrais e atividade hipoglicemiante de Rhynchelytrum repens (Willd.) C.E. Hubb. (Poaceae)

A irradiância é um fator crucial em reações vitais para o crescimento e desenvolvimento das plantas. A utilização da energia radiante pelos vegetais afeta diferentes respostas em relação ao padrão de desenvolvimento e à produção de matéria seca e sua conseqüente distribuição. Tendo em vista a intrínseca relação entre disponibilidade de luz, acúmulo de biomassa e metabolismo de carboidratos e compostos relacionados, os objetivos deste trabalho foram avaliar o efeito da irradiância sobre o conteúdo e a composição dos carboidratos não-estruturais, sobre o desenvolvimento e sobre a atividade hipoglicemiante de Rhynchelytrum repens, uma gramínea pantropical de origem africana utilizada popularmente no tratamento de diabetes. O cultivo a pleno sol (PS) estimulou aumento no conteúdo de carboidratos solúveis totais (CST), no perfilhamento das plantas e nas flutuações do conteúdo de amido (CA). O florescimento dessas plantas foi precedido por um aumento de CST, especialmente de sacarose. Foi observado também menor conteúdo de água nas plantas sob PS quando comparado com as plantas cultivadas sob irradiância reduzida (IR). Nesta última condição, o CA e a razão raiz/parte aérea não sofreram alterações significativas, porém houve 
aumento no conteúdo de CST ao longo do período experimental, menor grau de perfilhamento e formação de raízes adventícias aéreas. Em ambas as condições de luminosidade, a sacarose foi o açúcar mais abundante e com maiores variações. Esse açúcar parece estar envolvido nos processos de florescimento da espécie. Uma redução no nível de glicose plasmática foi observada a partir da administração do precipitado do extrato aquoso de $R$. repens obtido de plantas cultivadas em PS e IR, não havendo diferença significativa entre os tratamentos. A fração sobrenadante não apresentou efeito hipoglicemiante.

Palavras-chave: gramíneas tropicais, açúcares solúveis, atividade hipoglicemiante, baixa irradiância.

\section{INTRODUCTION}

Irradiance is the main environmental factor affecting plant growth and biomass production. Many metabolic processes are stimulated by light, which regulates photosynthetic activity at different levels in higher plants (Astolfi et al., 2001).

Light availability also affects patterns of establishment of grasses growing in forests, where incidence of light presents many fluctuations. In this type of habitat, many herbaceous species respond positively to light increase (Riegel et al., 1992, 1995). Studies comparing grasses with different photosynthetic metabolism showed that $\mathrm{C}_{4}$ species are more sensitive than $\mathrm{C}_{3}$ species to low irradiance, which promotes lower fitomass production and later reproductive development (Naumburg et al., 2001). Acclimatization studies carried out with three $\mathrm{C}_{4}$ grasses showed that modifications in irradiance level during development lead to an adjustment of photosynthetic activity in these species (Sailaja \& Das, 1995). Differences in irradiance also cause significant changes in leaf growth pattern. Leaves of wheat cultivated under high irradiance differ in morphology, composition, and photosynthetic characteristics from those grown under low irradiance (Lichtenthaler, 1981; Lichtenthaler et al., 1981).

Many tropical grass species, especially those from Africa, have been considered invaders of American natural reserves (Mantovani, 1983) because of their high capacity of replacing native species (Pivello et al., 1999). Carbohydrate metabolism plays a preponderant role in shoot biomass production, one of the main parameters for dominance determination. Variations in these compounds as to their chemical nature, proportion, and localization in the tissues occur depending on plant development and environmental features (Lewis, 1984).

Sucrose and starch, the most common products of photosynthesis, accumulate during the day and are mobilized at night, guaranteeing continuous photosynthate availability for the plant. However, many species do not use sucrose and starch as the primary source of carbon, but alternatively accumulate sucrosiloligosaccharides such as fructans, raffinose family oligosaccharides (RFOs), or alditols like manitol and sorbitol instead (Büchi et al., 1998).

Rhynchelytrum repens, popularly used as an anti-diabetic (Filgueiras, 2000, in De Paula, 2002), has not been thoroughly studied as to carbohydrate metabolism, especially soluble sugars and growth. Although native to Africa, this $\mathrm{C}_{4}$ annual grass species is widespread in tropical regions, growing rapidly in open areas (Lorenzi, 1991).

A number of metabolic changes were observed in species growing under limited irradiance (Willenbrink et al., 1998). In plants with therapeutic potential like Rhynchelytrum repens, these changes generally include differences in composition, content, and proportion of compounds of pharmacological interest (Prakasa-Rao et al., 1985; Dudai et al., 1992; Palomino et al., 1997). However, many controversies involve the use of phytotherapeutic products because of variations caused by environmental conditions, including radiant energy.

Considering the wide distribution, mainly in open areas, of Rhynchelytrum repens, this work aimed at verifying the effect of irradiance on the growth pattern of the species, the distribution of non-structural carbohydrates, and also the relationship between those parameters and the hypoglycemic activity presented by plants cultivated under limited irradiance in comparison with specimens grown in natural environments.

\section{MATERIAL AND METHODS}

\section{Plant material and general procedures}

In October and November 1999 near Campinas (SP), about 300 seeds of Rhynchelytrum repens were harvested in natural populations and placed in special trays containing a commercial substrate (Plantmax - Eucatex). Twenty-five days after 
germination, 72 plants were transferred to pots containing $5 \mathrm{~kg}$ of forest soil. The pots were kept in a greenhouse for 5 days and then transferred to the field, where they were numbered and distributed onto two tables, one under natural irradiance ranging from $1700-2000 \mu \mathrm{mol}$ photons $\mathrm{m}^{-2} \mathrm{~s}^{-1}$ and the other under conditions of $75 \%$ irradiance reduction.

In both treatments, plants were randomly divided into three blocks; carbohydrate analyses were performed at the beginning of the experiment and after 15, 30, 45, and 60 days. For each analysis two plants from each block were used, resulting in twelve plants divided into shoot and root. Part of the material was used for water content determination.

On analysis days, all plants had their development evaluated according to Haun's scale (Haun, 1973), which determines a value for each tiller based on the total number of completely expanded leaves plus a decimal value calculated to the youngest leaf (not expanded) relative to the size of the previous one (completed expanded). This method was proposed because other systems do not define growth stages that are easily subdivided or continuous, i.e., linear, relative to the development of specific plant parts.

\section{Extraction and analysis of non-structural carbohydrates}

Water-soluble carbohydrates were extracted according to a procedure modified from Pollock \& Jones (1979). Extractions were performed with 1 $\mathrm{g}$ of fresh material, using ethanol $80 \%$ at $80^{\circ} \mathrm{C}$ for $5 \mathrm{~min}$, followed by filtration. This procedure was repeated twice. The residue was re-extracted twice in distillated water at $60^{\circ} \mathrm{C}$ for $20 \mathrm{~min}$. Ethanolic and water extracts were pooled and concentrated under vacuum. Total sugars were measured using the phenol-sulfuric acid procedure (Dubois et al., 1956) using glucose as the standard. Concentrated extracts were deionized using Sep-Pack Accell Plus QMA and CM cartridges; hydrophobic compounds were removed using Sep-Pack $\mathrm{tC}_{18}$ cartridges (Waters).

Neutral soluble carbohydrates were analyzed and quantified by high performance anion exchange chromatography with pulsed amperometric detection (HPAEC/PAD) using a $4 \times 250 \mathrm{~mm}$ CarboPac PA-1 column on a Dionex System Mod. DX 300 (USA), according to Itaya et al. (1997). The gradient was established by mixing eluant $A$ (deionized water) with eluant B ( $200 \mathrm{mM}$ sodium acetate) as follows: 0-2 min, $\mathrm{NaOH} 12 \mathrm{mM}$; 2-5 min, $\mathrm{NaOH} 24 \mathrm{mM}$; 5-9 min,
$\mathrm{NaOH} 44$; 9-13 min, $\mathrm{NaOH} 54 \mathrm{mM}$; 13-16 min, $\mathrm{NaOH}$ $62 \mathrm{mM}$; 16-18 min, $\mathrm{NaOH} 66 \mathrm{mM}$; $18-25 \mathrm{~min}, 96 \mathrm{mM}$; 25-30 min, NaOH 120 mM; 35-40 min, NaOH 140 $\mathrm{mM}$; and $41 \mathrm{~min}, \mathrm{NaOH} 12 \mathrm{mM}$. The applied PAD potentials for E1 (540), E2 (100), and E3 (50) were $0.10,0.60$, and -0.60 , respectively, and the output range was $1000 \mathrm{nA}$.

Starch extraction and analysis were performed according to the method proposed by Arêas \& Lajolo (1980), modified as follows: $10 \mathrm{mg}$ of ground dry material was weighed in an Eppendorf tube and submitted to extraction with ethanol $80 \%(\mathrm{v} / \mathrm{v})$ at $80^{\circ} \mathrm{C}$. After centrifugation at $10,000 \times g$ for $5 \mathrm{~min}$, the supernatant was discarded. This procedure was repeated thrice. The residue was transferred to a test tube, and $5 \mathrm{ml}$ of deionized water were added. The tubes were kept in a water bath at $100^{\circ} \mathrm{C}$ for $2 \mathrm{~h}$, and the residues were lyophilized. The material was solubilized in $2 \mathrm{ml}$ of $\alpha$-amilase in $100 \mathrm{mM} 3$-[N-morpholin] propan-sulfonic acid buffer (MOPS), $\mathrm{pH} 7.0$, and incubated at $30^{\circ} \mathrm{C}$ for $2 \mathrm{~h}$. After centrifugation at $10,000 \times g$ for $5 \mathrm{~min}$, $300 \mu \mathrm{l}$ of the supernatant were transferred to an Eppendorf tube containing $1.2 \mathrm{ml}$ of amiloglucosidase in $100 \mathrm{mM}$ sodium acetate buffer, $\mathrm{pH}$ 5.5. The mixture was incubated at $30^{\circ} \mathrm{C}$ for $3 \mathrm{~h}$ and the reaction was stopped by the addition of $150 \mu \mathrm{l}$ of $0.8 \mathrm{M}$ perchloric acid. Of this mixture, $20 \mu 1$ was transferred to a tube and $150 \mu \mathrm{l}$ of glucose oxidase peroxidase with 2,2' azino-bis(3-etilbenzotiazoline-6-sulfonic) acid (ABTS) was added. After incubation at $30^{\circ} \mathrm{C}$ for $15 \mathrm{~min}$, free glucose was quantified by spectrophotometry at 540 $\mathrm{nm}$.

\section{Assay of hypoglycemic activity}

In order to check the hypoglycemic activity of low and high molecular weight compounds present in hot water extracts from $R$. repens, another experiment was performed with plants growing under natural and low irradiance. In this case, the aqueous extract was subjected to precipitation by the addition of three volumes of absolute ethanol, and kept overnight at $5^{\circ} \mathrm{C}$. The material was centrifuged 3 times, each of which for $10 \mathrm{~min}$, at $18,000 \times \mathrm{g}$. These procedures yielded two fractions, the precipitate and supernatant. After concentration under reduced pressure until complete dryness, the fractions were ressuspended in distilled water, and the hypoglycemic activity was assayed by plasma glucose analysis for $1,2,3,4,5,6$, and $24 \mathrm{~h}$ after administration in streptozotocin-induced diabetic rats according to the procedure of Pepato et al. (1993). The fractions, 
corresponding to $2.6 \mathrm{~g}$ of dry matter for each rat, were administered intraperitoneally.

The statistical significance of the difference among treatments was tested using one-way ANOVA peformed using the Jandel Scientific 1994 software package.

\section{RESULTS AND DISCUSSION}

Water soluble carbohydrate (WSC) and water content of plants of $R$. repens cultivated under natural and low irradiance are presented in Table 1. After marked fluctuations at the beginning of the experiment, WSC levels increased from 30 days of treatment until the end of the experiment. The WSC content was higher in plants grown under natural irradiance, mainly at 30 and 45 days, and the water content was lower when compared to those from plants grown under low irradiance.

As shown in Fig. 1, plants cultivated under natural irradiance showed higher levels of starch until 45 days of treatment, but between 45 and 60 days of growth a decrease occurred concomitantly with the WSC increase (Table 1). After 45 days, the number of starch grains was consistently higher in plants grown in NC (E. S. Alves, Institute of Botany, São Paulo, personal comunication).

In plants grown under low irradiance (LI), WSC content also increased after 30 days of treatment, and at 60 days these levels did not differ from those found in plants cultivated in natural conditions (Table 1). During the whole experimental period, starch content remained practically unchanged in plants cultivated under LI (Fig. 1), and at day 60 the values were the same as those found for plants under natural irradiance (NI). This probably occurred because of WSC content decrease in NI and not of a WSC level increase in plants grown under LI.

Similar results were found in rice plants grown under four irradiance conditions. In this study, starch content was less affected by irradiance than was WSC content. On the other hand, stem analyses showed that WSC levels were higher in plants cultivated under natural irradiance, while starch levels were higher in plants grown under LI (Conocono et al., 1998).

As emphasized by Lichtenthaler et al. (1981, 1982), under high irradiance higher plants usually present smaller leaves, higher dry weight, lower water content, high chlorophyll a/b ratio, and faster development when compared to plants grown under low irradiance. In the present study, lower water content was observed in plants of $R$. repens cultivated under NI.

Analysis by HPAEC/PAD (Fig. 2) showed that the main sugars found in Rhynchelytrum repens were glucose, fructose, and sucrose. Traces of raffinose were detected. Quantifications of the main soluble carbohydrates are shown in Fig. 3. Until 45 days, the contents of all analyzed sugars were higher in plants grown under natural conditions. An increase in the levels of those sugars, especially sucrose (Fig. 3C), between 30 and 45 days was clearly observed, followed by a decrease between 45 and 60 days of growth, the period when the plants flowered. On the other hand, in plants cultivated under LI a delay in the increase occurred between 45 and 60 days. Under this experimental condition, plants did not flower.

Sucrose is a molecule having many effects on plant metabolism. These effects are believed to be mediated by the modulation of gene expression, or by the control of protein turnover (Farrar et al., 2000). Variations in leaf assimilation and sink metabolism are generally associated with changes in soluble carbohydrate content. In the present study, the sink activity increase might be related to decrease in WSC levels, especially sucrose, during the period of flowering.

Sugars are believed to act as signaling molecules regulating the expression of many genes (Kock, 1996); they probably also affect various plant growth aspects, including flowering (Jang et al., 1997). Evidence suggests that, in most species, flowering is particularly affected by the sucrose level (Bernier et al., 1993), however, the mechanisms of the action of this sugar on flowering transition are not yet clear (Pollock $\&$ Farrar, 1996). On the other hand, recent studies with Arabidopsis thaliana demonstrated that high sucrose levels $(5 \% \mathrm{w} / \mathrm{v})$ in the culture medium results in a delay of flowering time. In this case, the effect of sucrose was more related to vegetative growth stimulation, which delayed floral transition (Ohto et al., 2001).

Although many authors believe that temperature is the main environmental factor determining global plant distribution (Berry \& Björkman, 1980), irradiance is a primordial feature in the establishment of some habitats. In the case of Rhynchelytrum repens, besides the effect on biomass production and distribution, light played a preponderant role in reproductive behavior, since plants growing under low irradiance did not reach the flowering phase. Cessation of this normal pattern was preceded by a WSC content increase and seemed to be stimulated 
by a threshold level (about $6 \%$ of dry weight) of sugars. Under low irradiance, plants did not reach this value during the whole period. Besides phenological differences observed in plants cultivated under natural and low irradiance, the quantification of growth by Haun's Scale showed changes in the growth pattern of plants under both conditions (Fig. 4). Under NI, plants grew faster and had a higher number of tillers when compared with plants cultivated under low irradiance, which presented a delay in appearance tillers. Light seems to have affected photoassimilate distribution, since in plants cultivated under LI the growth in height was more pronounced. Under LI conditions, the nodes showed a larger diameter, and aerial adventitious roots formed (Fig. 5).

The WSC partitioning (Fig. 6) was also affected by irradiance, higher amounts being accumulated in shoots of plants grown under NI (Fig.
$6 \mathrm{~A})$, although at the beginning of the experiment no significant differences were found in WSC content between the shoot and the root. Differences were observed after 45 days. Under LI, however, significant differences were observed only 60 days after beginning the experiment (Fig. 6B). Under both conditions, WSC content in roots did not differ significantly during the entire experiment, indicating that the main changes in non-structural carbohydrates occurred in the shoot, and that these compounds were probably invested in the development of reproductive structures.

Similarly to what was observed in the present study, root development in maize genotypes under conditions of limiting light availability is much more reduced than that of shoot growth, resulting in a decreased root/shoot ratio (Hébert et al., 2001).

In different grass species, WSC content reduction caused by low irradiance, as well as by

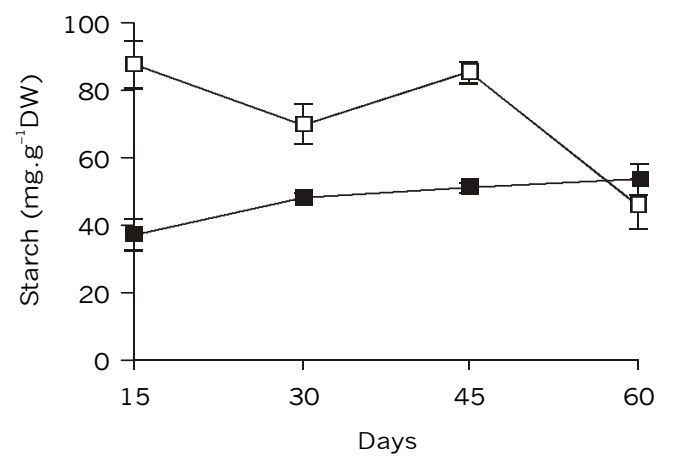

Fig. 1 - Starch content in shoots of Rhynchelytrum repens grown under natural ( $\square$ ) and low (ם) irradiance conditions. Bars indicate \pm s.e.

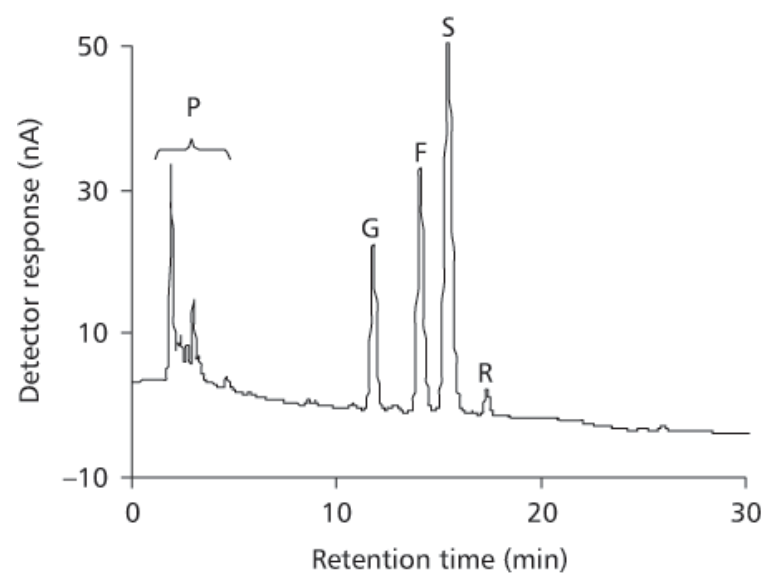

Fig. 2 - HPAEC-PAD analysis of water soluble carbohydrates in shoots of Rhynchelyrum repens grown under natural conditions. $\mathrm{P}$ - polyols, $\mathrm{G}$ - glucose, $\mathrm{F}$ - fructose, $\mathrm{S}$ - sucrose, $\mathrm{R}$ - raffinose. 
A

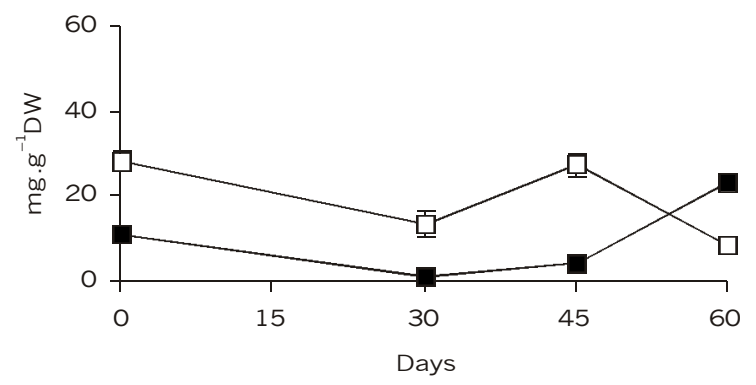

B

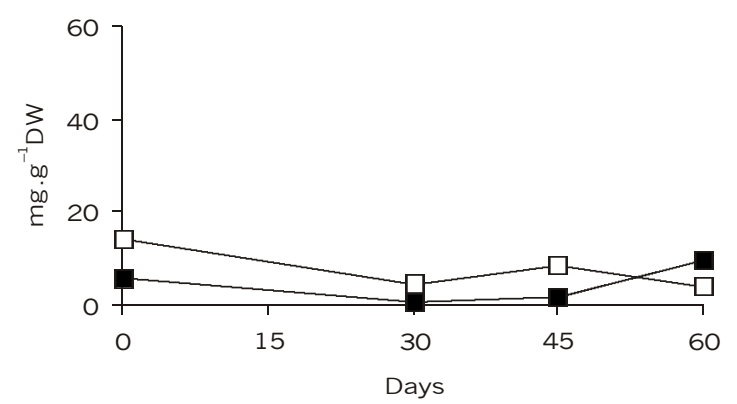

C

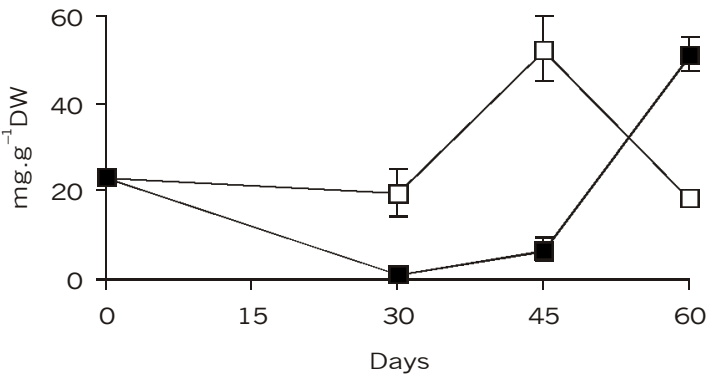

Fig. 3 - Glucose (A), fructose (B), and sucrose (C) contents in shoots of Rhynchelytrum repens grown under natural ( $\square$ ) and low (ם) irradiance conditions. Bars indicate \pm s.e.

TABLE 1

Water soluble carbohydrates (WSC) and water content in plants of Rhynchelytrum repens grown under natural and low irradiance. Capital letters compare values horizontally and small letters compare values vertically $(\mathbf{p}<0.05, \mathbf{n}=3)$.

\begin{tabular}{|c|c|c|c|c|}
\hline \multirow{2}{*}{$\begin{array}{c}\text { Period of analysis } \\
\text { (days) }\end{array}$} & \multicolumn{2}{|c|}{$\begin{array}{c}\text { WSC } \\
\text { (mg.g }\end{array}$} & \multicolumn{2}{c|}{$\begin{array}{c}\text { Water content } \\
\text { (\%) }\end{array}$} \\
\cline { 2 - 5 } & Natural irradiance & Low irradiance & Natural irradiance & Low irradiance \\
\hline 0 & $50.46 \mathrm{aA}$ & $33.49 \mathrm{aA}$ & $83.4 \mathrm{aA}$ & $85.6 \mathrm{aA}$ \\
\hline 15 & $44.16 \mathrm{aA}$ & $59.72 \mathrm{aA}$ & $76.5 \mathrm{aA}$ & $88.3 \mathrm{aA}$ \\
\hline 30 & $34.50 \mathrm{aA}$ & $23.16 \mathrm{aB}$ & $75.4 \mathrm{aB}$ & $81.5 \mathrm{bA}$ \\
\hline 45 & $53.26 \mathrm{aA}$ & $30.9 \mathrm{aB}$ & $75.4 \mathrm{aB}$ & $81.7 \mathrm{bA}$ \\
\hline 60 & $63.88 \mathrm{aA}$ & $52.90 \mathrm{aA}$ & $74.4 \mathrm{aA}$ & $78.7 \mathrm{bA}$ \\
\hline
\end{tabular}



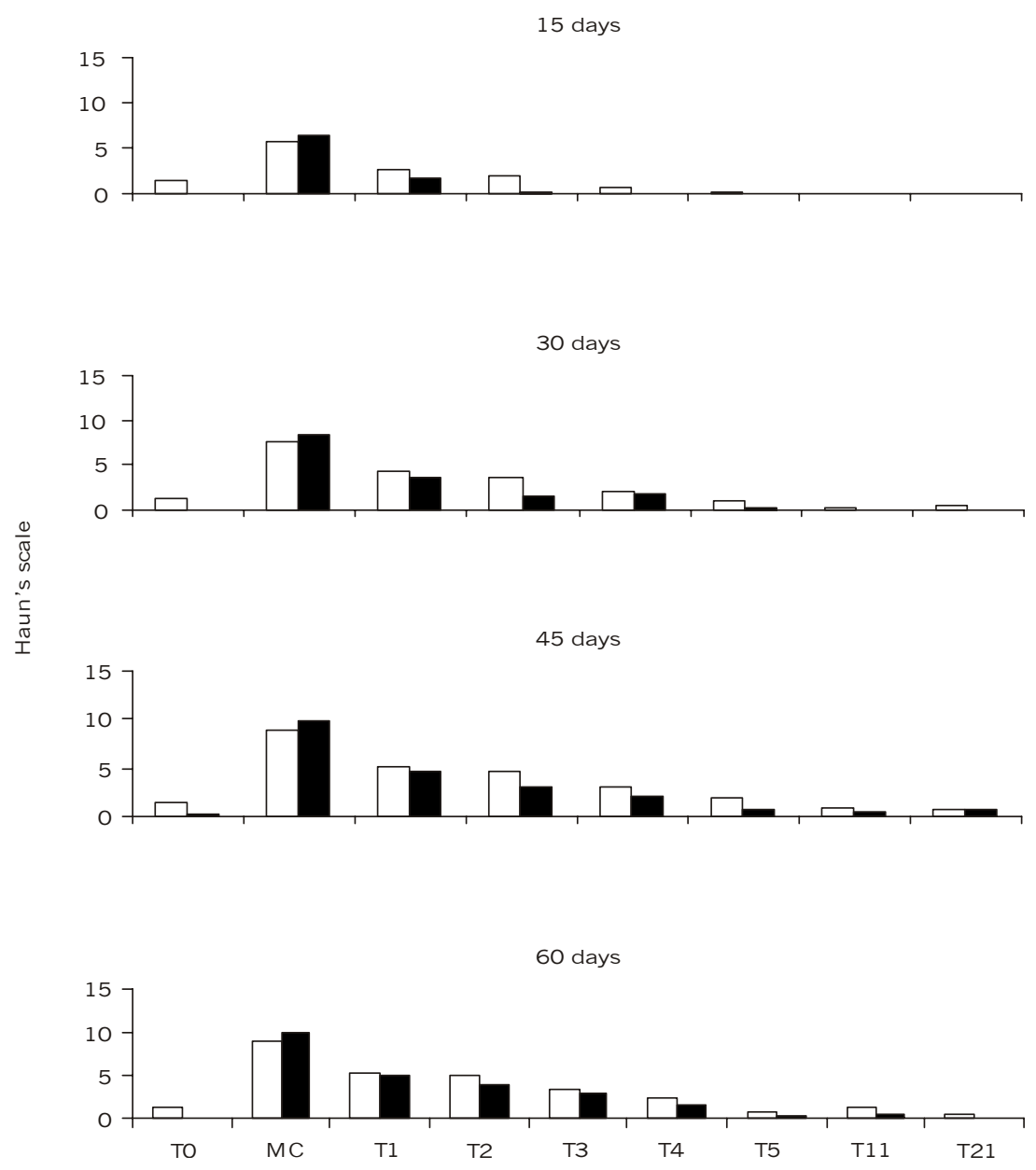

Fig. 4 - Visual quantification of the growth of the main culm (MC) and tillers (T0-T21) in plants of Rhynchelytrum repens grown under natural ( $\square$ ) and low ( $\square$ ) irradiance conditions.

natural or induced defoliation, leads to a decrease in the enzymes involved in sugar metabolism and an increase of proteolytic enzymes (James et al., 1993; Pollock \& Farrar, 1996; Dieuaide-Noubhani et al., 1997).

Studies carried out with rice under different levels of irradiance showed a positive correlation between photosynthetic rate and irradiance $\left(r^{2}=0.99\right)$, between soluble carbohydrates and irradiance, as well as between soluble carbohydrates and photosynthesis $\left(\mathrm{r}^{2}=0.98\right)$, indicating that carbohydrate levels reflect photosynthetic activity in response to irradiance (Conocono et al., 1998).

Knowing irradiance effects on plant growth is also fundamental in determining the number of plants to be cultivated per $\mathrm{m}^{2}$. Usually, a greater number of plants per area leads to changes in the root/shoot ratio, followed by morphological alterations in response to the competition for light (Pellerin \& Demotes-Mainard, 1992).

As shown in the present study, several changes were observed at 45 days of growth between plants of $R$. repens cultivated under low and natural irradiance that could be related with the hypoglycemic activity of plants grown under both conditions during this period. Despite the remarkable differences in growth pattern and in the content and composition of non-structural carbohydrates, only the precipitate fraction (PPT) of the aqueous extracts yielded under both conditions showed a significant effect in reducing plasma glucose levels in streptozotocin-induced dia- 
betic rats (Fig. 7). The levels decreased about $25 \%$ and $35 \%$ in relation to the initial values and to the control, respectively (Fig. 7A). The supernatant fraction did not exhibit any hypoglycemic activity (Fig. 7B). The obtained results indicated that Rhynchelytrum repens shows similar hypoglycemic activity under different conditions of light. Furthermore, they provide important information pertinent to future commercial-scale production of potential phytotherapeutical products from uniform material. These results also suggest that the compounds responsible for hypoglycemic activity in $R$. repens are not affected by irradiance, at least with respect to their composition and/or relative proportions. On the other hand, the possibility of quantitative changes cannot be discarded, since assimilation rates verified through the non-structural carbohydrate contents were very different under both conditions analyzed.

Considering that non-structural carbohydrates represent the main source of rapidly available energy for the plant and that they also supply the carbon skeleton necessary for the biosynthesis of several bioactive compounds, the present data could contribute to future exploitation of active compounds from plants species with potential for therapeutic use.

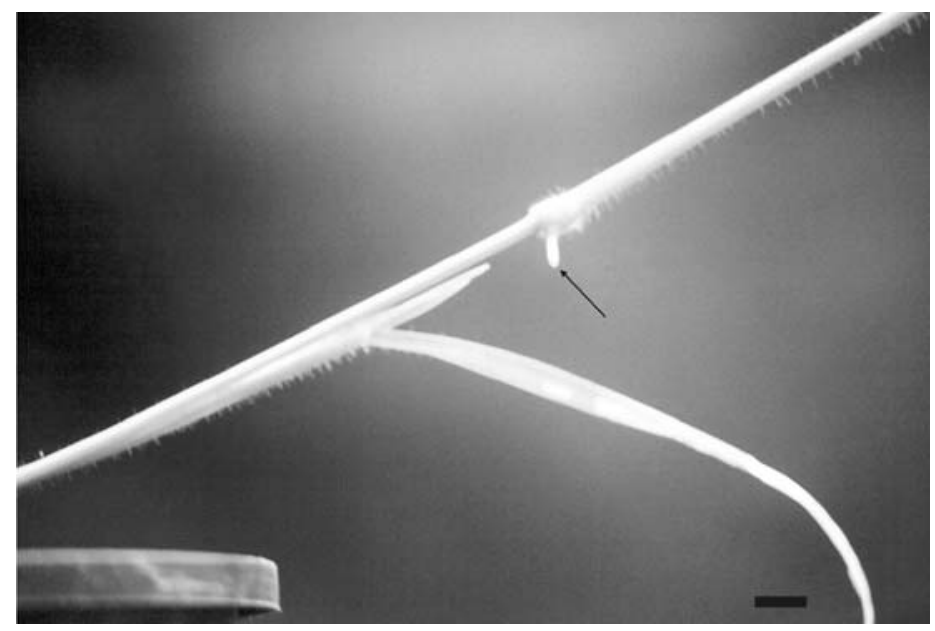

Fig. 5 - 45 day-old Rhynchelytrum repens plant cultivated under $75 \%$ reduced irradiance. The arrow indicates an adventitious root. $\mathrm{Bar}=1 \mathrm{~cm}$.

A

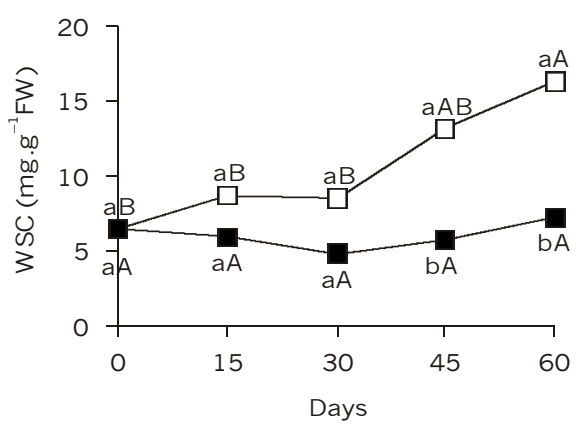

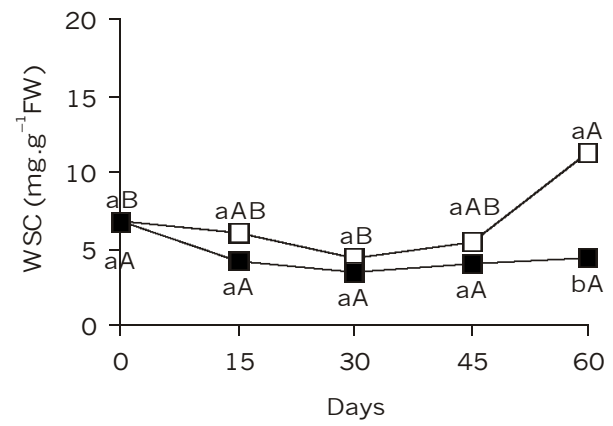

Fig. 6 - Water-soluble carbohydrates (mg. $\left.\mathrm{g}^{-1} \mathrm{FW}\right)$ in shoot $(\square)$ and root $(\mathbf{\square})$ of plants of Rhynchelytrum repens grown under natural (A) and low (B) irradiance conditions. Capital letters compare values horizontally and small letters compare values vertically $(\mathrm{p}<0.05, \mathrm{n}=3)$. 
A
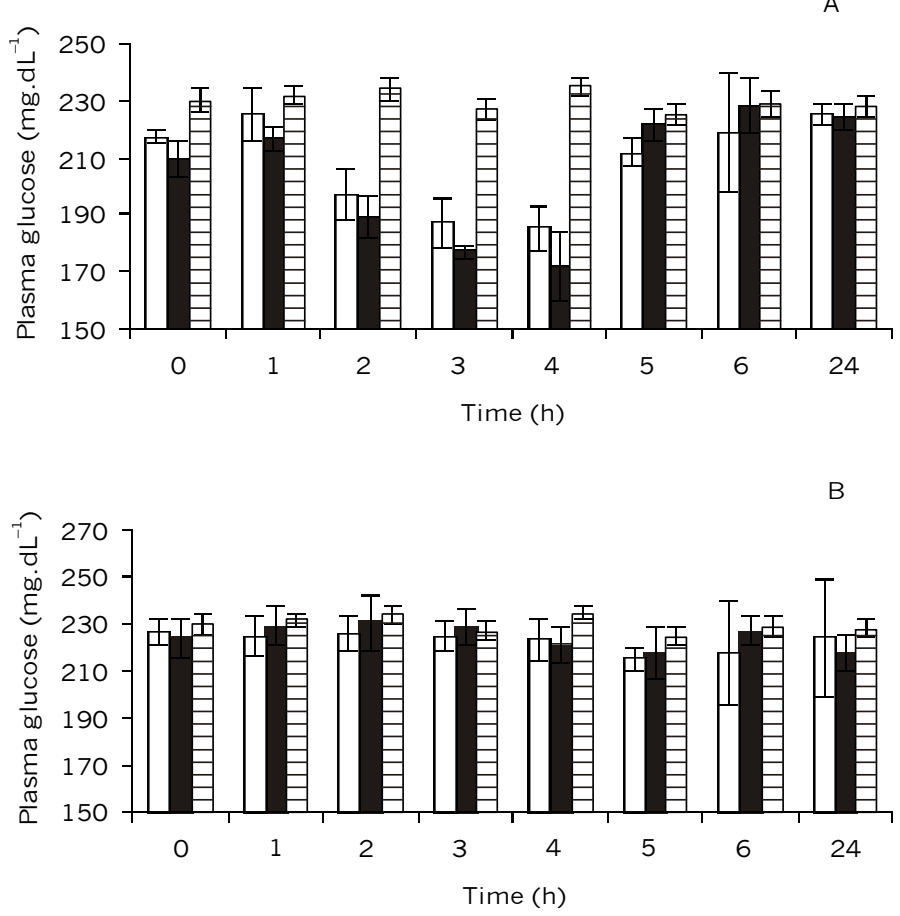

Fig. 7 - Effect of the precipitate (A) and the supernatant (B) from the aqueous extract of plants of Rhynchelytrum repens grown under natural $(\square)$ and low $(\square)$ irradiance conditions. Diabetic control $(\boxminus)$. $*$ Significantly different from the control, p $<0.05$ $(\mathrm{n}=10)$.

Acknowledgements - This work was supported by the State of São Paulo Research Foundation (FAPESP) within BIOTA/ FAPESP, and The Biodiversity Virtual Institute Program (http://www.biotasp.org.br). The authors thank Dr. Edenise Segala Alves for anatomic observations and critical revision of the manuscript, and to Henrique Pessoa dos Santos for helping the growth evaluation by Haun's scale. A. C. C. F. F. De Paula thanks the National Research Council for the Development of Science (CNPq) for a doctoral fellowship, and A. Souza thanks PIBIC/ $\mathrm{CNPq}$ for a fellowship. R. C. L. Figueiredo-Ribeiro is a researcher associated with $\mathrm{CNPq}$

\section{REFERENCES}

ARÊAS, J. A. G. \& LAJOLO, F. M., 1980, Determinação enzimática específica de amido, glicose, frutose e sacarose em bananas préclimatéricas e climatéricas. An. Farm. Quim. S. Paulo, 20: 307-317.

ASTOLFI, S., DE BIASI, M. G. \& PASSERA, C., 2001, Effects of irradiance-sulphur interactions on enzymes of carbon, nitrogen, and sulphur metabolism in maize plants. Photosynthetica, 39: 177-181.

BERNIER, G., HAVELANGE, A., HOUSSA, C., PETITJEAN, A. \& LEJEUNE, P., 1993, Physiological signals that induce flowering. Plant Cell, 5:1147-1155.

BERRY, J. \& BJÖRKMAN, O., 1980, Photosynthetic response and adaptation to temperature in higher plants. Ann. Rev. Plant Physiol., 31: 491-543.
BÜCHI, R., BACHMAN, M. \& KELLER, F., 1998, Carbohydrate metabolism in source leaves of sweet basil (Ocimum basilicum L.), a starch-storing and stachyosetranslocating Labiate. J. Plant Physiol., 153: 308-315.

CONOCONO, E. A., EGDANE, J. A. \& SETTER, T. L., 1998, Estimation of canopy photosynthesis in rice by means of daily increases in leaf carbohydrate concentrations. Crop Science, 38: 987-995.

DE PAULA, A. C. C. F. F., 2002, Carboidratos, flavonóides e atividade antidiabética de Rhynchelytrum repens (Willd.) C. E. Hubb, Capim-favorito (Poaceae). Ph.D Thesis, Universidade de São Paulo, São Paulo, 170p.

DIEUAIDE-NOUBHANI, M., CANIONI, P. \& RAYMOND, P., 1997, Sugar-starvation induced changes of carbon metabolism in excised root tips of maize. Plant Physiol, 115: 1505-1513.

DUBOIS, M., GILLES, A., HAMILTON, J. K., REBERS, P. A. \& SMITH, F., 1956, Colorimetric method of determination of sugars and related substances. Anal. Chem., 28: 350-355.

DUDAI, N., PUTIEVSKY, E., RAVID, U., PALEVITCH, D. \& HALEVY, A. H., 1992, Monoterpene content in Oryganum syriacum as affected by environmental conditions and flowering. Physiologia Plantarum, 84: 453-459.

FARRAR, J., POLLOCK, C. \& GALLAGHER, J., 2000, Sucrose and the integration of metabolism in vascular plants. Plant Science, 154: 1-11.

HAUN, J. R., 1973, Visual quantification of wheat development. Agronomy Journal, 65: 116-119. 
HÉBERT, Y., GUINGO, E. \& LOUDER, O., 2001, The response of root/shoot partitioning and root morphology to light reduction in maize genotypes. Crop Science, 41: 363-371.

ITAYA, N. M., BUCKERIDGE. M. S. \& FIGUEIREDO-RIBEIRO, R. C. L., 1997, Biosynthesis in vitro of high-molecular mass fructan by cell-free extracts from tuberosus roots of Viguiera discolor (Asteraceae). New Phytol., 136: 53-60.

JAMES, F., BROUQUISSE, R., PRADET, A. \& RAYMOND, P., 1993, Changes in proteolytic activity in glucose starved maize root tips regulation by sugars. Mant. Physiol. Biochem., 31: 845-856.

JANG, J. C., LEÓN, P., ZHOU, L. \& SHEEN, J., 1997, Hexokinase as a sugar sensor in higher plants. Plant Cell, 9: 5-19.

JERMYN, M. A., 1956, A new method for the determination of ketohexoses in the presence of aldohexoses. Nature, 117: 38-39.

KOCK, K. E., 1996, Carbohydrate-modulated gene expression in plants. Ann. Rev. Plant Physiol. Plant Mol. Biol., 47: 509540 .

LEWIS, D. H., 1984, Storage carbohydrates in vascular plants: distribution, physiology and metabolism. Cambridge University, London, 284p.

LICHTENTHALER, H. K., 1981, Adaptation of leaves and cloroplasts to high quanta fluence rates. In: G. Akoyunoglou (ed.), Photosynthesis, v. 6, p. 273-287.

LICHTENTHALER, H. K., BUSCHMANN, C., DÖLL, M., FIETZ, H. J., BACH, T., KOZEL, U., MEIER, D. \& RAHMSDORF, U., 1981, Photosynthetic activity, chloroplast ultrastructure, and leaf characteristics of high-light and low-light plants and of sun and shade leaves. Photosynth. Res., 2: 115-141.

LICHTENTHALER, H. K., KUHN, G., PRENZEL, U. \& MEIER, D., 1982, Chlorophyll-protein levels and degree of thylacoid stacking in radish chloroplast from high-light and low-light treated plants. Physiol. Plant., 56: 183-188.

LORENZI, H., 1991, Plantas daninhas do Brasil: terrestres, aquáticas, parasitas, tóxicas e medicinais. Ed. Plantarium, Odessa, 440p.

MANTOVANI, W., 1983, Composição e similaridade florística, fenologia e espectro biológico do cerrado da reserva biológica de Moji-Guaçu, Estado de São Paulo. Master Thesis, Unicamp, Campinas, 147p.

NAUMBURG, E., DEWALD, L. E. \& HOLB, T. E., 2001, Shade responses of five grasses native to southwestern U.S. Pinus ponderosa forests. Can. J. Bot., 79: 1001-1009

OHTO, M., ONAI, K., FURUKAWA, Y., AOKI, E., ARAKI, T. \& NAKAMURA, K., 2001, Effects of sugar on vegetative development and floral transition in Arabidopsis. Plant Physiology, 127: 252-261.
PALOMINO, O. M., GÓMEZ-SERRANILLOS, P., CARRETERO, E. \& CASES, A., 1997, Variation in the flavonoid content of Origanum x majoricum in different plant stages by HPLC. Planta Medica, 63: 584 .

PELLERIN, S. \& DEMOTES-MAINARD, S., 1992, Effect of competition for light between plants on the root shoot ratio and the number of adventitious roots of maize. $I n$ : L. Kutschera (ed.), Proc 3. ISSR Symposium root ecology and its practice application, Vienna. Verein für Wurzelforschung, Klagenfurt, Austria.

PEPATO. M. T., OLIVEIRA, J. R., KETTELHUT, I. C. \& MIGLIORINI, R. H., 1993, Assessment of the antidiabetic activity of Myrcia uniflora extracts in streptozotocin diabetic rats. Diabetes Research, 22: 49-57.

PIVELLO, V. R., SHIDA, C. N. \& MEIRELLES, S. T., 1999, Alien grasses in Brazilian savannas. Biodiversity \& Conservation, 8: 1281-1294.

POLLOCK, C. J. \& FARRAR, J. F., 1996, Source-sink relations: the role of sucrose. In: N. R. Backer (ed.), Photosynthesis and environment, pp. 261-279.

POLLOCK, C. J. \& JONES, T., 1979, Seasonal patterns of fructan metabolism in forage grasses. New Phytol., 83: 915.

PRAKASA-RAO, E. V. S., SINGH, M. \& GANESHA-RAO, R. S., 1985, Effect of plant spacing and application of nitrogen fertilizer on herb and essential oil yields of palmarosa (Cymbopogon martini Stapf. var motia). J. Agric. Sci., 104: 67-70.

RIEGEL, G. M., MILLER, R. F. \& KRUEGER, W. C., 1992, Competition for resources between understory vegetation and overstory Pinus ponderosa in northeastern Oregon. Ecol. Appl., 2: 71-85.

RIEGEL, G. M., MILLER, R. F. \& KRUEGER, W. C., 1995, The effects of aboveground and belowground competition on understory species composition in a Pinus ponderosa forest. For. Sci., 41: 864-889.

SAILAJA, M. V. \& DAS, V. S. R., 1995, Regulation of photosynthetic carbon metabolism by limiting irradiance in three different $\mathrm{C}_{4}$ plants. Photosynthetica, 31: 509-516.

SMITH, D., 1981, Removing and analyzing total nonstructural carbohydrate from plant tissue. Research Report 41. University of Wisconsin, Madison.

WILLENBRINK, J., BONNETT, G. D., WILLENBRINK, S. \& WARDLAW, I. F., 1998, Changes of enzyme activities associated with the mobilization of carbohydrate reserves (fructans) from the stem of wheat during kernel filling. New Phytol., 139: 471-478. 